\title{
ANALÝZA SPÁR MEZI PREFABRIKOVANÝMI SEGMENTY ŠTÍHLÝCH MOSTNÍCH KONSTRUKCÍ
}

\author{
ANALYSIS OF JOINTS BETWEEN PRECAST SEGMENTS OF SLENDER \\ BRIDGE STRUCTURES
}

\author{
Marek Velešík ${ }^{*}, 1$, Radim Nečas $^{1}$ \\ *velesik.m@fce.vutbr.cz \\ ${ }^{1}$ Vysoké učení technické v Brně, Fakulta stavební, Ústav betonových a zděných konstrukcí, Veveří 331/95, 60200 Brno, Česká republika
}

\begin{abstract}
Abstrakt
U štíhlých mostních konstrukcí, jako jsou předpjaté pásy a visuté konstrukce, je mostovka často realizována prostřednictvím prefabrikovaných segmentů. Spáry mezi prefabrikovanými segmenty jsou však zdrojem diskontinuit a mohou být kritickým místem z hlediska životnosti těchto konstrukcí. Na základě toho byl navržen experiment, při kterém bylo detailněji vyšetřováno chování spár mezi prefabrikovanými segmenty v provozním stavu. Podrobnější zkoumání těchto konstrukčních detailů může zpřesnit přístupy k jejich modelování. Součástí práce je i studie vlivu zalomení střednice v softwaru Midas Civil.
\end{abstract}

\section{Klíčová slova}

Štíhlé mostní konstrukce, předpjaté pásy, prefabrikované segmenty, spáry, isolinie normálových napětí

\begin{abstract}
Slender bridge structures, such as stress ribbon bridges and suspension bridges, are frequently constructed by precast segments. However, the joints between the precast segments are a source of discontinuities and can be critical in terms of the service life of these structures. An experiment was therefore designed to investigate the behaviour of the joints between the precast segments in service state in more detail. A closer investigation of these structural details can refine approaches to numerical modelling of these structures. The thesis also includes a study of the effect of centreline kinking in Midas Civil software.
\end{abstract}

Key words

Slender structures, stress ribbon bridges, precast segments, joints, isolines of the normal stresses

\section{1 ÚVOD}

Potřeba experimentálního ověření spár mezi prefabrikovanými segmenty u štíhlých mostních konstrukcí vzešla z řady již realizovaných visutých konstrukcí i konstrukcí předpjatého pásu. Př́ikladem pak může být nedávno navržená konstrukce předpjatého pásu v Národním parku Tyresta ve Švédsku. U analýzy těchto prefabrikovaných konstrukcí prostřednictvím výpočetních softwarů vyvstává otázka, jak přistoupit k modelování styku mezi jednotlivými prefabrikáty. V tomto článku je dále podrobněji popsán experiment, jehož účelem je stanovit průběh trajektorie napětí v oblasti diskontinuity styku segmentů. Na základě poznatků bude možné definovat vhodný přístup k modelování studovaných konstrukčních detailů, jež mohou být stěžejní pro životnost prefabrikovaných štíhlých mostních konstrukcí. Bez jejich správného návrhu a následné analýzy nelze zaručit bezpečnost a předpokládaná životnost zmíněných konstrukcí.

\section{POPIS KONSTRUKCE}

Navržený předpjatý pás se nachází v národním parku Tyresta a překonává západní záliv jezera Albysjön, čímž vytváří př́stupovou cestu do národního parku ze severu. Konstrukce lávky je tvořena monolitickými opěrami a mostovkou z prefabrikovaných segmentů s monolitickými náběhy do opěr - Obr. 1. Délka přemostění je 74,0 m, rozpětí hlavního pole s uvažováním teoretických podpěr je $75,0 \mathrm{~m}$ a celková délka mostu je $86,0 \mathrm{~m}$. Průchozí 
prostor lávky je 3,0 m. Maximální podélný sklon je u opěr 8,0 \% a zmenšuje se směrem k nejnižšímu bodu v polovině rozpětí.

Konstrukce není tvořena samokotveným systémem a je tedy třeba zachytit značnou vodorovnou reakci. K tomu slouží skupina skalních kotev pod monolitickou opěrou, která přenáší horizontální složky od nosných a předpínacích lan do skalního podloží.
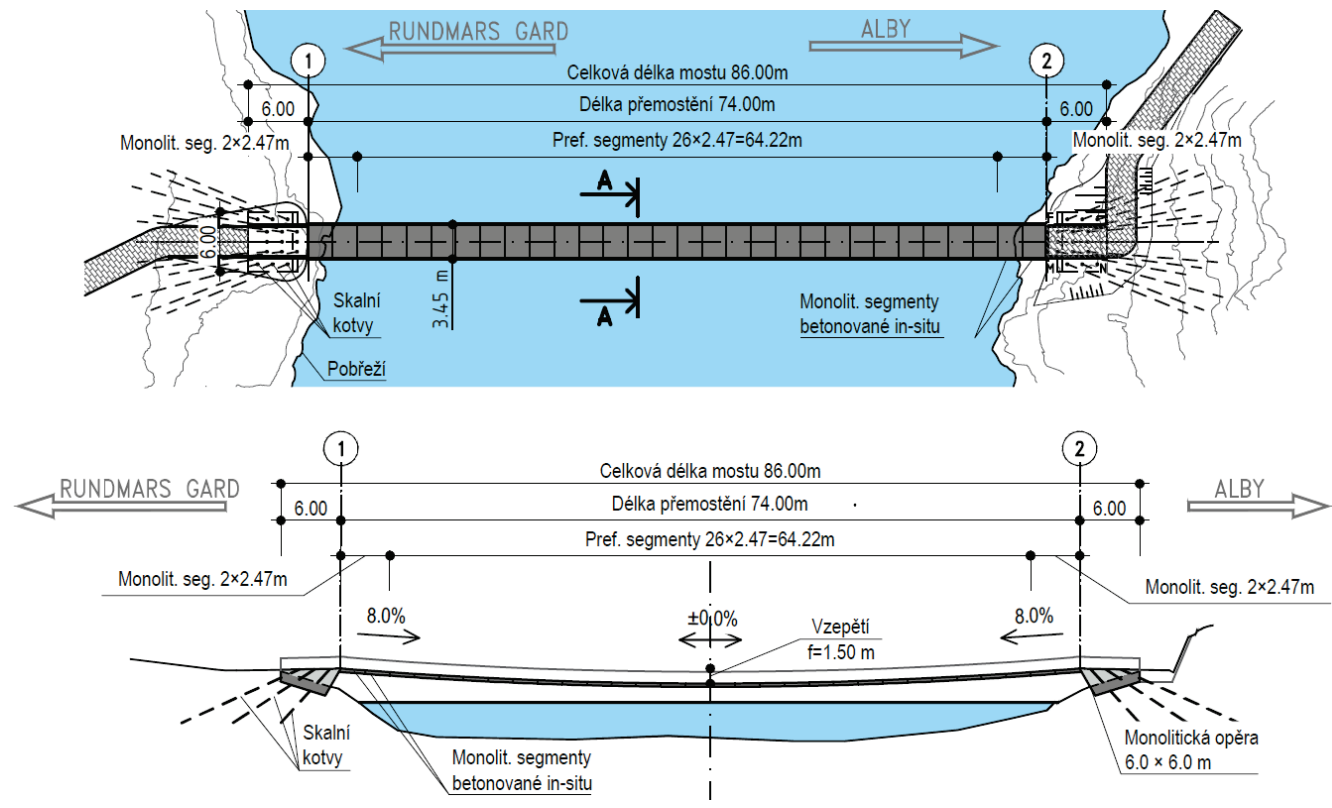

Obr. 1 Půdorys a podélný řez předpjatým pásem v NP Tyresta.

První dva krajní segmenty u opěr jsou betonovány in-situ s průběžnou podélnou betonářskou výztuží. Vnitřní segmenty jsou prefabrikované a jsou podpírány nosnými kabely. Jejich šířka je 3,45 m a délka je 2,47 m - Obr. 2. Ozub v místě styku segmentů sloužící pro betonáž spár má výšku $30 \mathrm{~mm}$ a délku $25 \mathrm{~mm}$. Celková šířka spáry mezi prefabrikovanými segmenty je $50 \mathrm{~mm}$. V prưřezu se kromě 2 nosných lan taktéž nachází finální předpínací lana, jež do mostovky vnášejí tlakovou rezervu.
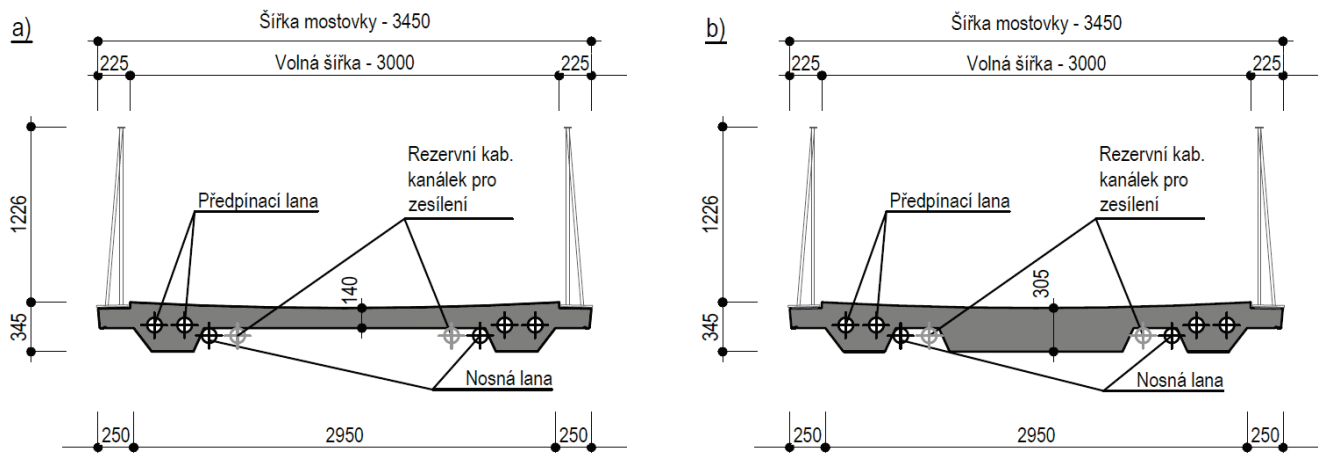

Obr. 2 Př́íný řez předpjatým pásem v NP Tyresta vedený a) prefabrikovaným segmentem, b) monolitickým náběhem. 


\section{EXPERIMENT A JEHO CÍLE}

Za účelem experimentální analýzy chování spár mezi segmenty byly navrženy zkušební fragmenty železobetonových segmentů třech různých tvarů. Spojením dvou shodných segmentů a zalitím vzniklé spáry, vzniká pak zkušební prvek, jež je předepnut předpínacími lany. Tímto způsobem odpovídá namáhání spáry reálnému provozu konstrukce. Při návrhu štíhlé prefabrikované konstrukce, je možné volit různé tvary segmentů, spár a odlišné uspořádání nosných a předpínacích lan. Vzhledem k tomu je experiment rozšířen o další dvě varianty (varianta 2 a 3), které spolu s variantou 1 vystihují základní možnosti uspořádání lan vůči tvaru prefabrikátu a tvaru spáry. Možné varianty provedení předpjatých pásů jsou popsány v [1].

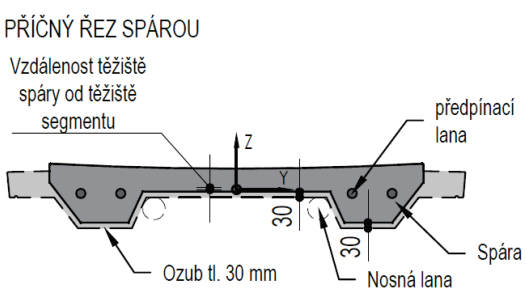

PODÉLNÝ ŘEZ SEGMENTEM

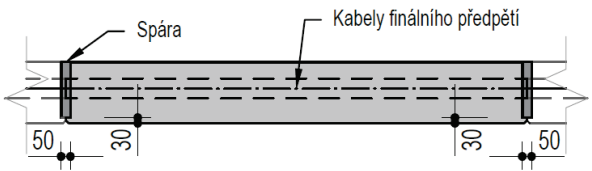

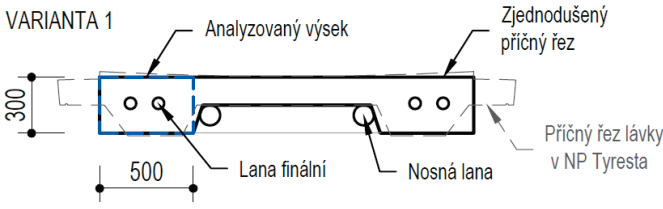

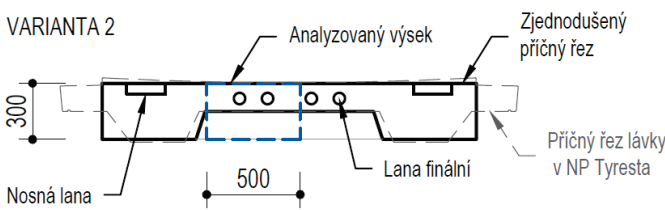

VARIANTA 3

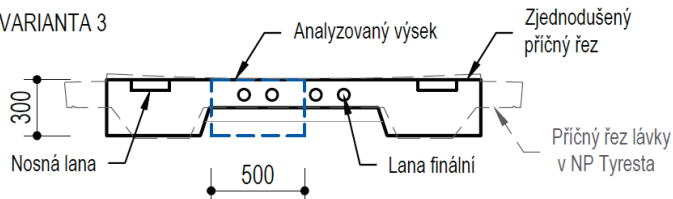

Obr. 3 Geometrie příčného řezu realizované konstrukce a její zjednodušení pro definici zkušebních těles.

\section{Modelová podobnost a zkušební tělesa}

S ohledem na výrobu vzorku a následnou manipulaci s ním, nejsou vyrobeny celé prefabrikované segmenty, ale pouze dílčí části $\mathrm{v}$ měřítku $\mathrm{M}=1: 1.5$ - Obr. 3. Taktéž je uplatněna přímá fyzikální podobnost mezi reálnou konstrukcí a vyráběným zkušebním vzorkem. Způsob návrhu usnadnil výrobu a snížil ekonomické náklady prováděného experimentu.

Tím, že je pro zkušební tělesa zvolen obdobný materiál jako pro skutečnou konstrukci a jsou dodržena pravidla modelové podobnosti, bude možné měřit ve spáře stejná napětí jako na skutečné konstrukci [2]. U zkoušek, při nichž by hrála roli i vlastní tíha vzorku, by dle principů podobnosti vyplývalo, že pro získání odpovídajících hodnot napětí, je nutné zvýšení vlastní tíhy (napr. balastním zatížením) [3]. Vzhledem k charakteru zkoušky, kde vlastní tíha roli nehraje, není třeba prrídavné zatížení zohledňovat.

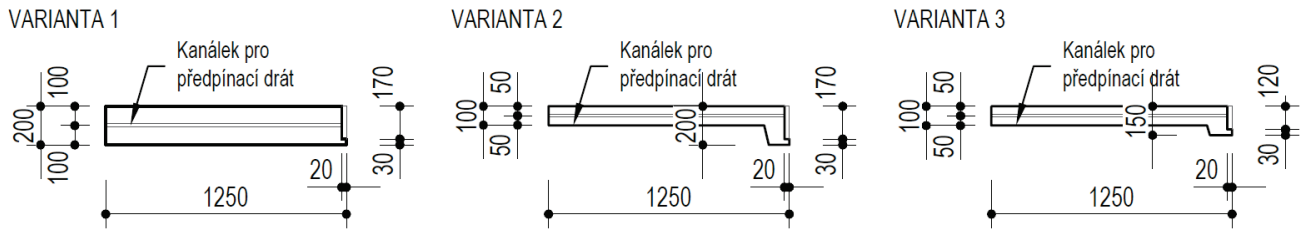

Obr. 4 Podélný řez zkušebními vzorky.

Zkušební tělesa jsou tvořena železobetonovými segmenty o šířce $325 \mathrm{~mm}$ a rozdílné výšky. Ozub v místě spáry je pro všechny vzorky shodný s výškou $30 \mathrm{~mm}$. Vzorek varianty 1 má konstantní výšku $200 \mathrm{~mm}$ s výškou spáry $170 \mathrm{~mm}$. Vzorek varianty 2 a 3 má výšku 100 mm a v místě spáry se rozšiřuje na výšku $200 \mathrm{~mm}$ resp. $150 \mathrm{~mm}$, výška spáry je pak $170 \mathrm{~mm}$ resp. $120 \mathrm{~mm}$ - Obr. 4. V polovině výšky vzorku jsou po šířce rovnoměrně vedeny 
3 trubky ø 20 mm tvořící kabelové kanálky pro následné vedení předpětí. S ohledem na zaměření experimentu na sledování spáry je v podélném směru délka vzorku shodná s polovinou délky segmentu.

Vzorek je vyztužen betonářskou výztuží - Obr. 5, tak aby splňoval konstrukční zásady dle [4] a nedošlo k jeho porušení účinky štěpných sil od předpětí. Předpětí je vnášeno do vzorku přes ocelovou kotevní desku prostřednictvím třech předpínacích lan Y1860S7-15.7 mm, tak aby ve spáře bylo vyvozeno tlakové napětí okolo 10,0 MPa. Pevnostní tř́da betonu segmentu je C30/37. Na spáru byl použit rychletuhnoucí beton C50 dle [5].
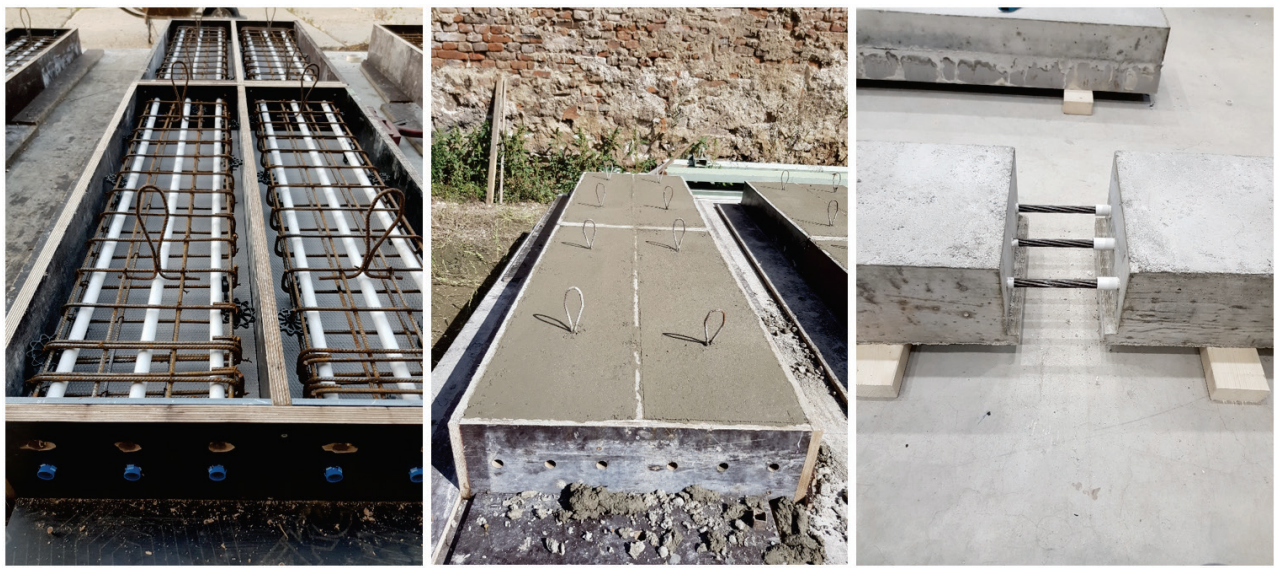

Obr. 5 Fotodokumentace výroby vzorků - armokoš, betonáž, zajištění separace předpětí ve spáře.

\section{Průběh zkoušky a měřicí technika}

Přibližně po 24 h po vybetonování spár mezi segmenty bylo pomocí napnutí předpínacího lana vyvozeno ve spáře tlakové napětí 1.0-2.0 MPa. Kontaktní napětí ve spáře zamezí vzniku trhlin mezi betonem segmentu a betonem spáry v důsledku smršt’ování. Po dosažení vyšších pevností betonu spáry (cca 1 týden) je vzorek předepnut na finální hodnoty, tak aby ve spáře bylo vyvozeno tlakové napětí mezi 10,0-12,0 MPa. Tím bude zkoumán stav odpovídající provoznímu stavu spáry na skutečné konstrukci.

Pro účely měření byly po výšce v místě spáry osazeny tři tenzometry typu LY41-50/120 - Obr. 6. Tyto lineární tenzometry jsou vhodné pro měření poměrných deformací v jednom směru. Mají nominální odpor $120 \Omega$, jejich měřící mřižka je vyrobena z konstantanu a materiál nosiče je polyimid. K přichycení na očistěný a hladký povrch betonu bylo použito dvousložkové rychle vytvrzující lepidlo X60.
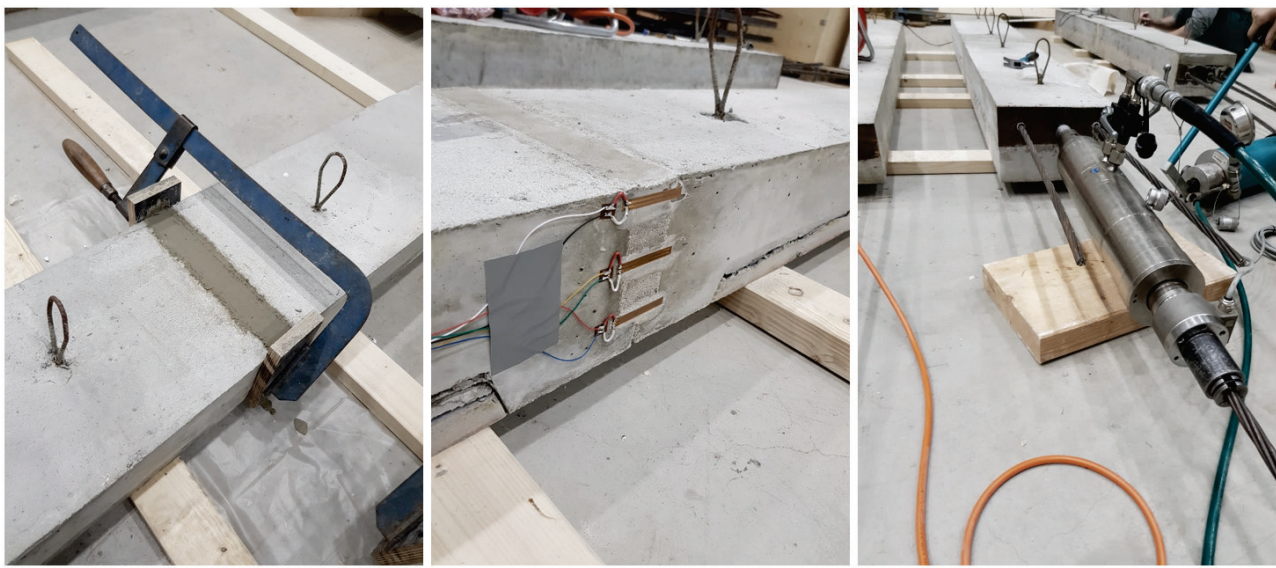

Obr. 6 Fotodokumentace zkoušení vzorků - zalití spáry, osazení měřičů a předpínání vzorku. 


\section{GLOBÁLNÍ ANALÝZA PŘEDPJATÉHO PÁSU}

Jedním z hlavních cílů experimentu je stanovení trajektorie napětí a stanovit, zda při analýze $\mathrm{v}$ místě spáry zalomovat střednici prutu či nikoliv- - Obr. 7. V globálním modelu zalomení střednice způsobuje výraznou skokovou změnu napjatosti v prưřezu a tím výrazně zesložituje návrh, kdy bývá zpravidla požadováno, aby ve spáre $\mathrm{v}$ charakteristické kombinaci nevznikalo tahové napětí, popř́padě byla ve spáře tlaková rezerva. Očekává se, že pro variantu 2 nebude zalomení střednice zdaleka tak výrazné jako předurčuje geometrie segmentu a spáry, ale autorem článku nebyla nalezena experimentální studie, která by to prokazovala.

a)

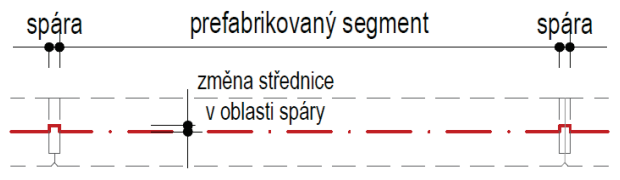

b)

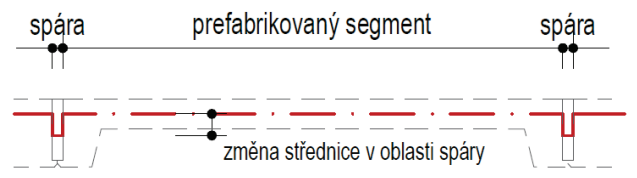

Obr. 7 Změna střednice nosné konstrukce v podélném směru a) střednice prutu odpovídající variantě 1, b) střednice prutu odpovídající variantě 2 a 3.

Pro názornost byl vytvořen globální výpočtový model konstrukce předpjatého pásu, kde je srovnáván vliv zalomení stř̌ednice. Výpočtový model je vytvořen v prostředí softwaru Midas Civil pro předpjatý pás obdobného rozpětí a vzepětí jako je konstrukce v národním parku Tyresta. Rozpětí konstrukce ve studii bylo uvažováno $70,0 \mathrm{~m}$, vzepětí $1,5 \mathrm{~m}$ a délka segmentů je prodloužena na $3,5 \mathrm{~m}$ zejména pro lepší čitelnost zobrazovaných výsledků v grafech. První model znázorňuje mostovku bez změny střednice o konstantní výšce $0,30 \mathrm{~m}$. Druhý model reprezentuje konstantní mostovku výšky $0,30 \mathrm{~m}$ s výškou spáry $0,25 \mathrm{~m}$. Střednice tedy v místě spáry skáče o 0,025 m směrem vzhůru. Třetí model znázorn̆uje mostovku výšky $0,20 \mathrm{~m} \mathrm{~s}$ žebry v místě spáry výšky $0,30 \mathrm{~m}$ a spáru s výškou $0,25 \mathrm{~m}$. Střednice tedy v místě spáry opět skáče o $0,025 \mathrm{~m}$, ale směrem dolů. Čtvrtý model znázorňuje chování modelu 3, ve kterém nedochází ke skoku střednice v místě žebra (ve spáře je skok uvážen). Model vychází z předpokladu, že by isolinie napětí procházely skrze žebro, aniž by zatekly do jeho spodní části.

Hlavní namáhání spár je zatížení od předpětí finálních lan. Druh namáhání se následně odvíjí od polohy finálních lan vzhledem k těžišti spáry. V grafu - Obr. 8 lze vidět, že při zalomení stř̌ednice dochází ke skokovým změnám ohybových momentů a jejich hodnoty dosahují $140 \mathrm{kNm}$ při změně střednice pouze $0,025 \mathrm{~m}$. To je způsobeno značnou předpínací sílou, která zajišt’uje tlakovou rezervu v průřezu.

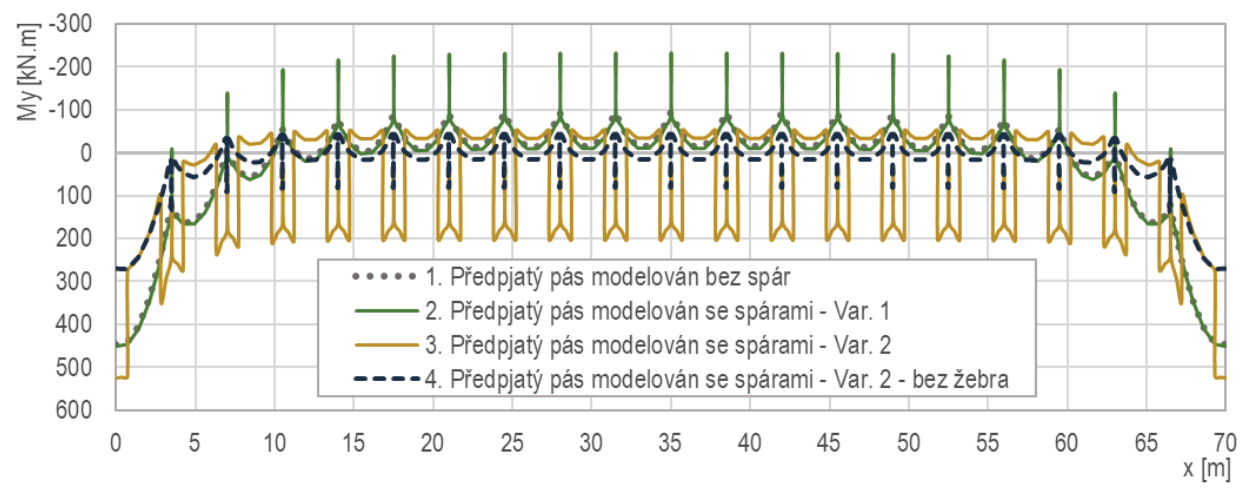

V grafu - Obr. 9 je pak znázorněn průběh napětí na horních a dolních vláknech pro jednotlivé modely. Ve všech modelech je navrhnuto shodné finální předpětí. Lze vidět, že v modelu 1 máme tlakovou rezervu 4,0 MPa. U modelů 2 a 3, lze naopak vidět, že s takovýmto návrhem jen těsně nedochází ke vzniku tahových napětí už ve výchozím stavu. Takovouto názornou analýzou můžeme vidět vliv různých př́istupů modelování a jaký vliv může mít odlišný přístup na bezpečnost a ekonomickou stránku návrhu. 

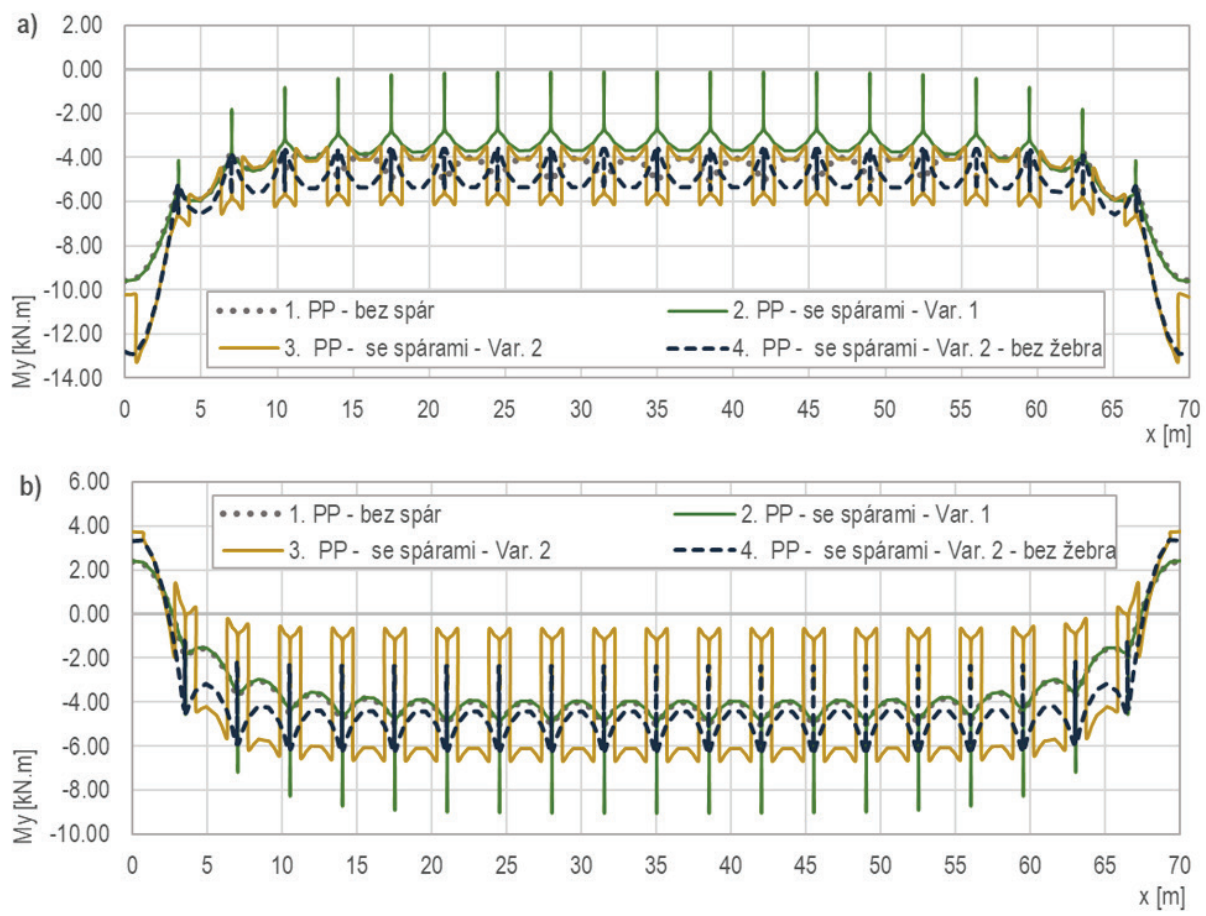

Obr. 9 Studie vlivu zalomení střednice - průběh efektivních napětí a) horní vlákna, b) dolní vlákna.

\section{ZÁVĚR}

Visuté konstrukce a konstrukce předpjatých pásů jsou díky své vysoké technické a architektonické úrovni v současné době často upřednostňovány před konvenčními variantami přemostění. Ovšem díky své složitosti je třeba provést geometricky nelineární analýzu s velkými deformacemi. Z provedené studie je patrné, že modelování střednice a její př́ípadné zalomení výrazně ovlivňuje návrh z hlediska zajištění požadavků na tlakovou rezervu ve spáře. Při dosavadních návrzích bylo nutné brát zřetel na tvar spáry vůči tvaru segmentu a konzervativně vyšetřovat i vliv zalomení střednice na rozdělení napětí. Vhodným návrhem by mohlo být shodování těžiště spáry a těžiště segmentu tak, aby k zalomení střednice nedocházelo, což ale nemusí být vždy proveditelné. Navrhnutý experiment bude sloužit k ověření trajektorie napětí, která nám odhalí, zda při analýze zalomovat střednici v místě spár, či nikoliv.

\section{Poděkování}

Článek vznikl za finanční podpory projektů FAST-S-21-7409 a FAST-J-21-7299.

\section{Použité zdroje}

[1] STRÁSKÝ, Jiří. Stress ribbon and cable-supported pedestrian bridges. London: Thomas Telford, 2005. ISBN 07277-3282-X

[2] NEČAS, R., Segmentové konstrukce se spřaženou deskou. Návrh, výroba a zkouška modelu, Vysoké učení technické v Brně, Fakulta stavební, Ústav betonových a zděných konstrukcí, Brno, 2006.

[3] KOLÁČEK, J., Analýza půdorysně zakřivených zavěšených a visutých lávek. Brno, Vysoké učení technické v Brně, Stavební fakulta, Ústav betonových a zděných konstrukcí, Brno, 2012

[4] ČSN EN 1992-1-1 ed. 2 (731201) Navrhování betonových konstrukcí - Č́st 1-1: Obecná pravidla a pravidla pro pozemní stavby, Praha, Úřad pro technickou normalizaci, metrologii a státní zkušebnictví, 2019

[5] C ČSN EN 13813 (722481) Potěrové materiály a podlahové potěry - Potěrové materiály - Vlastnosti a požadavky, Praha, Český normalizační institut, 2003 